\title{
Personal Experience with Clofazimine in the Treatment of Leprosy
}

\author{
R. D. AZULAY \\ Av. Atlantica 3130, Apt. 701, Copacabana, \\ Rio de Janeiro, Brazil,
}

and

\author{
N. C. DA SILVA, A. ZEO, M. DE JeSUS AND C. B. FRANCA \\ Institute of Leprology and Hospital of the Curupaity Colony, \\ Rio de Janeiro, Brazil
}

\begin{abstract}
The authors present the results obtained with 20 patients in an advanced stage of longstanding lepromatous leprosy, 15 of whom had sulphone resistant bacilli.

(1) Clofazimine has definite activity in leprosy and in patients with sulphone resistant bacilli.

(2) Activity is shown by resolution of the lesions and disappearance of bacilli.

(3) Clofazimine does not precipitate leprosy reaction as is seen in patients taking dapsone.

(4) Side-effects are negligible and do not interfere with treatment.
\end{abstract}

\section{Introduction}

Since Barry et al. (1957) showed that a phenazine compound named B-663 had anti-tuberculous activity, several reports were presented showing that the drug also had definite activity in leprosy. Browne and Hogerzeil (1962) published the first results of the treatment of 16 cases of lepromatous and borderline leprosy patients with B-663. Later on Browne (1965) confirmed those results and, in addition, suggested that the drug had anti-inflammatory action in that the frequency of lepra reaction was considerably lower than with dapsone treatment. Many other papers have since appeared, confirming these results.

\section{Our Experience}

We treated 20 patients with advanced lepromatous leprosy who presented the characteristics detailed in Tables 1 and 2 .

The group consisted of adults, predominantly male, all Brazilian except for one Portugese, who had had leprosy for periods ranging from 1 to 28 years, 16 patients having had leprosy for more than 10 years. Fifteen out of the 20 patients had been treated before as may be seen from Tables 3 and 4 .

Fif teen patients had been treated previously with a sulphone, either alone or associated with other drugs. Judging from the duration of therapy, (over 5 years in 14 patients) and from the failure of treatment, we may probably deduce that these patients harboured sulphone resistant organisms. 
TABLE 1

All patients were in-patients of the Curupaity Hospital, grouped as follows

\begin{tabular}{lr}
\hline & No. of cases \\
\hline Sex & 16 \\
Male & 4 \\
Female & \\
Colour & 12 \\
White & 3 \\
Black & \\
Nationality & 19 \\
Brazilian & 1 \\
Portuguese & \\
Age & 2 \\
$15-19$ & 1 \\
$20-29$ & 10 \\
$30-39$ & 4 \\
$40-49$ & 2 \\
$50-59$ & 1 \\
$60-69$ & \\
\hline
\end{tabular}

TABLE 2

\begin{tabular}{cc}
\hline Duration of illness & No. of cases \\
\hline $0-4$ years & 3 \\
$5-9$ years & 1 \\
$10-14$ years & 3 \\
$15-19$ years & 5 \\
$20-24$ years & 6 \\
$25-30$ years & 2 \\
\hline
\end{tabular}

TABLE 3

Previous therapy

\begin{tabular}{cc}
\hline Duration in years & No. of cases \\
\hline $0-4$ & 1 \\
$5-9$ & 2 \\
$10-14$ & 1 \\
$15-19$ & 5 \\
$20-25$ & 5 \\
$25-30$ & 1 \\
\hline
\end{tabular}


TABLE 4

Previous therapy

\begin{tabular}{lc}
\hline Drugs & No. of cases \\
\hline Sulphone & 3 \\
Sulphone plus thiambutosine & 6 \\
Sulphone plus thiambutosine plus thiacetazone & 2 \\
Sulphone plus isonicotinyl Hydrazide (INH) & 1 \\
Sulphone plus thiambutosine plus INH & 2 \\
Sulphone plus Tebessal & 1 \\
\hline
\end{tabular}

TABLE 5

Therapeutical results of clofazimine on 20 patients suffering from advanced lepromatous leprosy (L 3)

\begin{tabular}{lcccccc}
\hline \multirow{2}{*}{$\begin{array}{l}\text { Duration of } \\
\text { treatment }\end{array}$} & $\begin{array}{c}\text { Previous } \\
\text { treatment }\end{array}$ & Complete & Marked & Discrete & None & Total \\
\hline \multirow{2}{*}{$\begin{array}{lccc}\text { 1 year } \\
\text { Yes }\end{array}$} & 0 & 2 & 1 & 0 & 3 \\
& No & 1 & 2 & 1 & 0 & 4 \\
2 years & Yes & 1 & 9 & 2 & 0 & 12 \\
\multirow{2}{*}{ Total } & No & 0 & 0 & 1 & 0 & 1 \\
\hline
\end{tabular}

Urine analysis, blood levels of glucose and nitrogen, blood counts and bacteriological examination of nasal mucosa, skin and ear-lobe, as well as biopsy were performed both before and during treatment.

\section{Present Treatment}

The patients were treated with clofazimine for 5 years; during the first months of treatment, the daily dose was $200 \mathrm{mg}$, which was then reduced to $100 \mathrm{mg}$ daily.

\section{Results}

\section{Clinical}

Tables 5 and 6 show the results of the treatment on the skin lesions. Bacteriological

Table 7 shows the results after 2 and 5 years of treatment. 
TABLE 6

Therapeutical results of clofazimine in 20 patients suffering from advanced lepromatous leprosy (I,3)

\begin{tabular}{lcccc}
\hline $\begin{array}{l}\text { Duration of } \\
\text { treatment }\end{array}$ & $\begin{array}{c}\text { Previous } \\
\text { treatment }\end{array}$ & Complete & Marked & Total \\
\hline \multirow{2}{*}{5 years } & Yes & 15 & 0 & 15 \\
Total & No & 3 & 2 & 5 \\
\hline
\end{tabular}

TABLE 7

Overall results of bacterioscopic tests on 20 patients treated with clofazimine

Results of bacterioscopic tests

\begin{tabular}{lcccc} 
& \multicolumn{2}{c}{ Positive } & \multicolumn{2}{c}{ Negative } \\
& 2 years & 5 years & 2 years & 5 years \\
\hline Before & 20 & 20 & 0 & 0 \\
After & 10 & 0 & 10 & 20 \\
\hline
\end{tabular}

\section{Histopathological}

Histopathological examination were performed before, during, and after 2 years of treatment, i.e. 3 per patient. The results of the 5 year study are not yet available. Some histopathological findings seen after 2 years of treatment should be emphasized.

(1) Reduction of the leprotic infiltration.

(2) Considerably reduced bacillary count.

(3) Granular and fragmented forms were more numerous than solid staining forms of the bacillus.

(4) The Virchow cells disappeared. These cells increased in size, and showed marked lipid intra-cytoplasmic degeneration; they became practically free from bacilli.

(5) Of 12 patients who were histologically lepromatous before therapy, 8 became regressive.

(6) In some patients we found brownish pigmentation in both dermis and epidermis.

\section{Lepra reaction}

We tried to observe the action of the drug in relation to lepra reaction. This is shown in Table 8.

There is no doubt that clofazimine has a definite action on lepra reaction. 
TABLE 8

Effect of clofazimine on leprotic reaction

\begin{tabular}{lccc}
\hline \multirow{2}{*}{ Frequency } & \multirow{2}{*}{ Before treatment } & \multicolumn{2}{c}{ After treatment } \\
& & 2 years & 5 years \\
\hline Very frequent & 3 cases & 0 & 0 \\
Frequent & 3 cases & 1 case & 0 \\
Rarely & 5 cases & 1 case & 0 \\
None & 9 cases & 18 cases & 20 \\
\hline
\end{tabular}

\section{Side-effects}

The following were observed: reddish pigmentation, dark pigmentation, ichthyosis like lesions of the skin and some dyspeptic symptoms. The dark pigmentation which was more intense in the first years of treatment improved with the resolution of the lesions.

\section{References}

Barry, V. C., Belton, J. G., Conalty, M. L., Dennemy, J. M., Edward, D. W., O’Sullivan, J. F., Twomey, D. and Winder, F. (1957). A few series of phenazines (rimino-compounds) with high anti-tuberculous activity. Nature (Lond.) 179, 1012-1015.

Browne, S. G. and Hogerzeil, L. M. (1962). B-633 in the treatment of leprosy. Preliminary report of a pilot trial. Lepr. Rev. 33, 182-184.

Browne, S. G. (1965). Treatment of leprosy with B-663. Appraisal of the pilot trial after three years. Lepr. Rev. 36, 13-15. 